Jurnal Hukum \& Pembangunan 46 No. 1 (2016): 90-105

ISSN: 0125-9687 (Cetak)

E-ISSN: 2503-1465 (Online)

\title{
AGREEMENT ON AGRICULTURE DALAM WORLD TRADE ORGANIZATION
}

\author{
Akbar Kurnia Putra \\ * Fakultas Hukum Universitas Jambi Program Kekhususan Hukum Internasional \\ Korespondensi: akbarkurniaputra@yahoo.com \\ Naskah dikirim: 4 Februari 2016 \\ Naskah diterima untuk diterbitkan: 5 Maret 2016
}

\begin{abstract}
Framework of agricultural trade liberalization in the context of World Trade Organization (WTO) General Agreement set out in the field of Agriculture or the Agreement on Agriculture (AOA). AOA is one of the international treaties that are generated through a series of WTO negotiations in the Uruguay Round of General Agreement on Tariffs and Trade (GATT). Pact is applied simultaneously with the establishment of the WTO on January 1, 1995 which contained 13 parts and 21Articles which is equipped with 5 Annex and an appendix to the Annex 5. The AoA has three main pillars, namely the expansion of market access, domestic support and export subsidies. Through Law No. 7 of 1994, Indonesia has ratified the WTO provisions which obliges WTO member states to adapt the rules contained in Annex WTO. One of them is the rules of the food policy Indonesia through Law No. 7 of 1996 concerning Food and Government Regulation No. 68 of 2002 on Food Security.
\end{abstract}

Keyword: WTO, AoA, Food, Food Security

\begin{abstract}
Abstrak
Kerangka liberalisasi perdagangan komoditi pertanian dalam konteks World Trade Organization (WTO) tertuang dalam Perjanjian Umum Bidang Pertanian atau Agreement on Agriculture (AOA). AOA adalah salah satu perjanjian internasional WTO yang dihasilkan melalui serangkaian perundingan dalam Putaran Uruguay dari General Agreement on Tariffs and Trade (GATT). Perjanjian ini diberlakukan bersamaan dengan berdirinya WTO pada tanggal 1 Januari 1995 yang terdiri atas 13 bagian dengan 21 Pasal yang dilengkapi dengan 5 Pasal Tambahan (Annex) dan satu lampiran untuk Annex ke-5. Adapun AoA memiliki tiga pilar utama yaitu perluasan akses pasar, dukungan domestik serta subsidi ekspor. Melalui Undang-Undang Nomor 7 Tahun 1994 Indonesia telah meratifikasi ketentuan-ketentuan WTO dimana WTO mewajibkan negara-negara anggotanya untuk menyesuaikan aturan-aturan yang termuat dalam Annex WTO.Salah satunya adalah aturanaturan kebijakan pangan Indonesia yaitu melalui Undang-undang Nomor 7
\end{abstract}


Tahun 1996 tentang Pangan dan Peraturan Pemerintah Nomor 68 Tahun 2002 tentang Ketahanan Pangan.

Kata kunci: WTO, AoA, Pangan, Ketahanan Pangan

\section{Pendahuluan}

\section{Latar Belakang}

Pangan merupakan kebutuhan manusia yang paling asasi, sehingga ketersediaan pangan bagi masyarakat harus selalu terjamin. Manusia dengan segala kemampuannya selalu berusaha mencukupi kebutuhannya dengan berbagai cara. Dalam perkembangan peradaban masyarakat untuk memenuhi kualitas hidup yang maju, mandiri, dalam suasana tenteram, serta sejahtera lahir dan batin, semakin dituntut penyediaan pangan yang cukup, berkualitas, dan merata. Oleh karena itu, kecukupan pangan bagi suatu bangsa merupakan hal yang sangat strategis. Sesuai dengan perkembangan era globalisasi dan liberalisasi perdagangan, beberapa komoditas pangan telah menjadi komoditas yang semakin strategis, karena ketidakpastian dan ketidakstabilan produksi pangan nasional, tidak selalu dapat secara otomatis mengandalkan kepada ketersediaan pangan di pasar dunia. Oleh karena itu, sebagian besar negaranegara menetapkan sistem ketahanan pangan untuk kepentingan dalam negerinya.

Selanjutnya kesepakatan pembentukan WTO merupakan realisasi dari cita-cita lama pada waktu merundingkan GATT pertama kali. ${ }^{1}$ Perjanjian perdagangan multilateral pertama yang diakui dunia adalah Perjanjian Umum tentang Tarif dan Perdagangan (General Agreement on Tariffs and Trade GATT) pada tahun 1948. Pada awalnya GATT ditujukan untuk membentuk International Trade Organization (ITO), suatu badan khusus PBB. ${ }^{2}$ Latar belakang pembentukan GATT dimulai dari pengalaman pahit depresi ekonomi dunia pada dasawarsa 1930-an, yang diikuti dengan pemberlakuan proteksi perdagangan oleh negara-negara besar. Sejak tahun 1948 - 1994, GATT mengadakan 7 (tujuh) putaran perundingan perdagangan multilateral dengan tujuan memfasilitasi perdagangan internasional. Dari berbagai Putaran Perundingan Perdagangan dalam sejarah GATT, yang terpenting adalah Putaran Tokyo dan Putaran Uruguay. ${ }^{3}$ Putaran Tokyo telah gagal untuk menyelesaikan masalah utama yang berkaitan dengan perdagangan produk pertanian dan penetapan persetujuan baru mengenai safeguards. Meskipun

36.

${ }^{1}$ Huala Adolf, "Hukum Perdagangan Internasional”, (Jakarta: Raja Grafindo Persada, 2005), hal.

${ }^{2}$ Ibid., hal. 103.

${ }^{3}$ Mochamad Slamet Hidayat, et.al., "Sekilas WTO (World Trade Organization)", Edisi Keempat, (Jakarta: Direktorat Perdagangan, Perindustrian, Investasi dan HKI Direktorat Jenderal Multilateral Departemen Luar Negeri, tanpa tahun), hal. 6. 
demikian, serangkaian persetujuan mengenai hambatan non-tarif telah muncul di berbagai perundingan, yang dalam beberapa kasus menginterpretasikan peraturan GATT yang sudah ada. ${ }^{4}$

Putaran Uruguay memakan waktu tujuh setengah tahun atau hampir 2 (dua) kali dari rencana jadwal semula, dengan 123 negara yang ikut berpartisipasi. Putaran tersebut hampir mencakup semua bidang perdagangan. Putaran Uruguay memberikan hasil yang nyata, hanya dalam waktu 2 (dua) tahun, para peserta telah menyetujui suatu paket pemotongan atas bea masuk terhadap produk-produk tropis dari negara berkembang, penyelesaian sengketa, dan agar para anggota memberikan laporan reguler mengenai kebijakan perdagangan. ${ }^{5}$ Hal ini merupakan langkah penting bagi peningkatan transparansi aturan perdagangan di seluruh dunia. World Trade Organization (WTO) merupakan satu-satunya badan internasional yang secara khusus mengatur masalah perdagangan antar negara. Sistem perdagangan multilateral WTO diatur melalui persetujuan yang berisikan aturan-aturan dasar perdagangan internasional yang dihasilkan oleh para negara anggota melalui proses negosiasi. Persetujuan tersebut merupakan perjanjian antar negara anggota yang mengikat pemerintah negara anggota untuk mematuhinya dalam pelaksanaan kebijakan perdagangan mereka. ${ }^{6}$

WTO didirikan negara anggotanya dengan maksud dan tujuan bersama sebagaimana dicantumkan dalam mukadimahnya sebagai berikut: ${ }^{7}$

Bahwa hubungan-hubungan perdagangan dan kegiatan ekonomi negara negara anggota harus dilaksanakan dengan maksud untuk meningkatkan standar hidup, menjamin lapangan kerja sepenuhnya, peningkatan penghasilan nyata, memperluas produksi dan perdagangan barang dan jasa, dengan penggunaan optimal sumber-sumber daya dunia sesuai dengan tujuan pembangunan berkelanjutan. Juga mengusahakan perlindungan lingkungan hidup dan meningkatkan cara-cara pelaksanaannya dengan cara-cara yang sesuai dengan kebutuhan masing-masing negara yang berada pada tingkat pembangunan ekonomi yang berbeda. Dalam mengejar tujuan-tujuan ini diakui adanya suatu kebutuhan akan langkah-langkah positif untuk menjamin agar supaya Negara berkembang, teristimewa yang paling terbelakang, mendapat bagian dari pertumbuhan perdagangan internasional sesuai dengan kebutuhan pembangunan ekonominya.Untuk mencapai tujuan-tujuan ini diadakanlah suatu pengaturan yang saling menguntungkan yang diarahkan pada pengurangan tarif secara substansial dan juga hambatan-hambatan non-tarif terhadap perdagangan, dan untuk menghilangkan perlakuan diskriminatif dalam hubungan perdagangan internasional.

${ }^{4}$ Hira Jhamtani, "WTO dan Penjajahan Kembali Dunia Ketiga", (Yogyakarta: INSISTpress, 2005), hal. 3.

${ }^{5}$ Mochamad Slamet Hidayat, Op. Cit.

${ }^{6}$ Ibid.

${ }^{7}$ Mukadimah dari Agreement Establishing The World Trade Organization. 
Diantara fungsi WTO yang terpenting adalah melancarkan pelaksanaan, pengadministrasian serta lebih meningkatkan tujuan dari perjanjian pembentukan WTO sendiri serta perjanjian-perjanjian lain yang terkait dengannya. ${ }^{8}$ Disamping itu WTO juga merupakan forum negosiasi bagi para anggotanya di bidang-bidang yang menyangkut perdagangan multilateral, forum penyelesaian sengketa, dan melaksanakan peninjauan atas kebijakan perdagangan.

Perjanjian-perjanjian WTO sangat luas dan kompleks sebab menyangkut berbagai bidang seperti tekstil dan pakaian, pertanian, perbankan, telekomunikasi, belanja negara (government procurement), standar industri, undang-undang sanitasi dan keamanan makanan, perlindungan hak kekayaan intelektual dan sebagainya. Namun demikian terdapat beberapa prinsip mendasar yang menaungi semua bentuk perjanjian dalam WTO yakni: ${ }^{9}$ Trade without discrimination (prinsip non-diskriminasi dalam perdagangan): (a) Most favoured nation (MFN): treating other people equally, (b) National treatment; Freer Trade: gradually, through negotiation (mencapai perdagangan bebas secara bertahap melalui negosiasi) ${ }^{10}$; Predictable (dapat diprediksi); Promoting fair competition (mendorong persaingan dagang yang adil); Encouraging development and economic reform (mendorong pembangunan dan pembaharuan ekonomi bagi negara miskin dan berkembang).

1) Trade Without Discrimination (Prinsip Non-Diskriminasi dalam Perdagangan)

a) Most favoured nation (MFN): treating other people equally

Dalam perjanjian WTO, semua negara diperlakukan sama. Artinya negara-negara anggota WTO tidak boleh melakukan diskriminasi terhadap mitra dagangnya dan tidak boleh ada perbedaan perlakuan antara produk domestiknya dengan produk impor. Kebaikan standar ini dalam bentuknya yang tak bersyarat adalah bahwa ia secara umum memberlakukan bagi seluruh peserta perjanjian keuntungan-keuntungan yang diberikan oleh salah satu dari mereka kepada negara ketiga. Prinsip ini merupakan landasan bagi tiga perjanjian WTO, yaitu GATT (artikel 1), GATS (artikel 2) dan TRIPS (artikel 4). ${ }^{11}$

${ }^{8}$ Hata, "Perdagangan Internasional dalam Sistem GATT dan WTO Aspek-Aspek Hukum dan Non Hukum", (Bandung: Refika Aditama, 2006), hal. 88.

${ }^{9}$ Understanding the WTO: Principles of the Trading System, World Trade Organization, diakses melalui situs internet <http://www.wto.org/english/thewto_e/whatis_e/tif_e/fact2_e.htm>, diakses tanggal 1 November 2011.

${ }^{10}$ Sejak GATT didirikan pada tahun 1947-1948 telah terjadi delapan putaran perundingan. Fokus pertama perundingan dikonsentrasikan pada penurunan tarif (bea masuk) terhadap produk impor. Sebagai hasilnya, pada pertengahan 1990-an negara-negara industri mulai menurunkan tariff produk-produk industri hingga turun secara tetap sekitar 4\%. Namun sejak tahun 1980-an, perundingan mulai melebar pada isu hambatan non-tarif dan isu-isu baru seperti bidang jasa dan kekayaan intelektual.

${ }^{11}$ Hata, Op. Cit., hal. 55. 


\section{b) National treatment}

Dalam prinsip ini produk lokal maupun produk impor harus diperlakukan sama. Prinsip perlakuan sama dengan produk nasional ini meliputi bidang jasa, merek, undang-undang hak cipta dan hak paten. Misalnya, pajak penjualan yang sama akan dikenakan bagi produk serupa yang dijual orang asing dan yang diperdagangkan warga negara sendiri. Prinsip ini merupakan landasan bagi tiga perjanjian WTO yaitu GATT (artikel 3), GATS (artikel 17) dan TRIPS (artikel 3). ${ }^{12}$

2) Freer Trade: Gradually, Through Negotiation (Mencapai Perdagangan Bebas Secara Bertahap Melalui Negosiasi)

Dalam prinsip ini mencapai perdagangan bebas dilakukan secara bertahap melalui negosiasi. Menurunkan hambatan perdagangan merupakan langkah nyata dalam mendorong perdagangan. Berbagai masalah hambatan perdagangan seperti bea masuk (tarif) dan larangan impor atau kuota yang membatasi kuantitas suatu produk secara selektif serta isu-isu lain seputar hambatan perdagangan seperti penggunaan label merah dan perubahan kebijakan nilai tukar juga didiskusikan dalam rangkaian negosiasi perdagangan. ${ }^{13}$

\section{3) Predictable (Dapat Diprediksi)}

Dengan adanya stabilitas dan prediktibilitas bagi dunia usaha maka iklim investasi dapat mendorong terciptanya lapangan pekerjaan, peluang-peluang bisnis dan keuntungan yang dapat dinikmati oleh konsumen dari ketersediaan berbagai jenis barang dengan harga murah sebagai akibat dari munculnya persaingan dagang yang sehat. Dengan adanya stabilitas dan prediktibilitas akan menurunkan hambatan perdagangan seperti kuota dan langkahlangkah lainnya yang bertujuan untuk membatasi masuknya produk impor.

\section{4) Promoting Fair Competition (Mendorong Persaingan Dagang Yang Adil)}

Dalam prinsip ini, persaingan dalam perdagangan dapat diterapkan secara adil. Sistem WTO masih memperkenankan penerapan tarif dan bentuk-bentuk proteksi dalam skala kecil. Melalui berbagai

\footnotetext{
${ }^{12}$ Ibid.

${ }^{13}$ Sejak GATT didirikan pada tahun 1947-1948 telah terjadi delapan putaran perundingan. Fokus pertama perundingan dikonsentrasikan pada penurunan tarif (bea masuk) terhadap produk impor. Sebagai hasilnya, pada pertengahan 1990-an negara-negara industri mulai menurunkan tariff produk-produk industri hingga turun secara tetap sekitar 4\%. Namun sejak tahun 1980-an, perundingan mulai melebar pada isu hambatan non-tarif dan isu-isu baru seperti bidang jasa dan kekayaan intelektual.
} 
tahapan liberalisasi perdagangan yang progresif, penerapan tarif dan kebijakan proteksi tersebut diharapkan dapat dihilangkan sepenuhnya sehingga kondisi perdagangan yang adil akan tercipta. Mekanisme MFN dan nationaltreatment diharapkan dapat mengurangi praktek dumping, subsidi serta hambatan-hambatan perdagangan lainnya.

5) Encouraging Development And Economic Reform (mendorong pembangunan dan pembaharuan ekonomi bagi negara miskin dan berkembang)

Sistem WTO dapat membawa kontribusi bagi pembangunan dan pembaharuan ekonomi bagi negara-negara berkembang. WTO memberikan kesempatan, kelonggaran waktu dan fleksibilitas yang besar serta berbagai perlakuan khusus untuk melakukan berbagai penyesuaian sebagai persiapan menuju pasar bebas. Berbagai kemudahan diberikan karena lebih dari 75 persen anggota WTO adalah negara-negara berkembang dan negara-negara yang sedang mengalami transisi ke arah ekonomi pasar.

Selain prinsip-prinsip perdagangan dalam WTO yang telah disebutkan di atas, adapun terdapat prinsip-prinsip negosiasi dalam WTO sebagai berikut: ${ }^{14}$

a. prinsip fundamental yang digunakan negara-negara dalam melakukan negosiasi di WTO adalah memperoleh keuntungan bersama;

b. asas resiprositas adalah ketika suatu negara mencari perbaikan akses di pasar negara lain (seperti penurunan tarif), negara tersebut harus siap pula untuk memberikan konsesi (seperti pengurangan tarif) yang dianggap menguntungkan atau memiliki nilai yang sama dengan konsesi yang diminta oleh mitra dagangnya tersebut. ${ }^{15}$

c. prinsip Single Undertaking merupakan prinsip dalam negosiasi di WTO yang didefinisikan sebagai "seluruh unsur dalam negosiasi merupakan bagian dari satu kesatuan utuh yang tidak bisa dibagibagi atau disetujui hanya sebagiannya saja." Prinsip ini dikenal juga sebagai konsep "nothing is agreeduntil everything is agreed."16

Dalam pertemuan keempat Konferensi Tingkat Menteri (KTM) World Trade Organization (WTO) di Doha, Qatar pada bulan November 2001, diadopsi sebuah agenda besar mengenai pembentukan putaran baru negosiasi perdagangan yang dikenal dengan nama Doha Development Round (DDR), atau Putaran Doha. Putaran Doha memiliki visi untuk membentuk konsep baru liberalisasi di bidang pertanian, tarif, jasa, rencana implementasi program,

\footnotetext{
${ }^{14}$ Mochamad Slamet Hidayat, Loc. Cit.

${ }^{15}$ Ibid.

${ }^{16}$ Ibid.
} 
potensi reformasi dalam sistem penyelesaian sengketa, serta empat bidang yang disebut dengan "Singapore Issues" yaitu persaingan usaha, investasi, transparansi dalam pengadaan barang pemerintah, dan fasilitas perdagangan. ${ }^{17}$ Di antara topik-topik perundingan tersebut, perjanjian pertanian menjadi perhatian negara berkembang karena sektor ini menjadi pilar ekonomi di banyak negara berkembang.

Pertanian dan persetujuan di bidang pertanian menjadi perhatian utama dalam negosiasi perdagangan, karena selama ini disadari sering terjadi distorsi perdagangan atas produk-produk pertanian yang disebabkan oleh pengenaan kuota impor dan pemberian subsidi domestik maupun subsidi ekspor. Ketentuan-ketentuan dalam GATT untuk bidang pertanian pada awalnya disadari banyak mengandung kekurangan dan kelemahan, sehingga pada putaran Uruguay negosiasi diusahakan untuk menghasilkan ketentuan di bidang pertanian yang adil (fair), dapat menjamin kompetisi yang sehat dan tidak distortif melalui penghapusan sistem kuota impor dan pemberian subsidi. Persetujuan bidang pertanian ini disepakati baik oleh negara maju maupun negara berkembang yang menjadi anggota OPD/WTO. Tujuan Persetujuan bidang pertanian ini adalah melakukan reformasi perdagangan dalam sektor pertanian dan membuat kebijakan-kebijakan yang lebih berorientasi pasar. Hal ini dapat memperkuat tingkat prediksi dan keamanan negara-negara pengimpor maupun pengekspor. Negara maju diwajibkan untuk mematuhi ketentuan ini dalam kurun waktu 6 tahun, sedangkan negara berkembang diberi waktu 10 tahun terhitung sejak 1 Januari $1995 .{ }^{18}$ Perjanjian mengenai pertanian masuk ke dalam WTO sebenarnya atas perjuangan negara sedang berkembang. Pada masa putaran Uruguay, negara berkembang merasa bahwa peraturan perdagangan internasional hanya menguntungkan negara maju karena aspek yang dicakupnya memberikan keuntungan komparatif kepada produk negara maju. Bertitik tolak dari uraian tersebut di atas, maka penulis tertarik untuk meneliti dan menulis permasalahan tersebut menjadi sebuah karya ilmiah dengan judul Agreement on Agriculture Dalam World Trade Organization

\section{Perumusan Masalah}

Berdasarkan uraian pada latar belakang masalah diatas, maka dirumuskan masalahnya yaitu, bagimanakah proses masuknya Agreement on Agriculture (AoA) ke dalam sistem World Trade Organization?

\footnotetext{
${ }^{17}$ Hira Jhamtani, Op. Cit., hal. 10.

${ }^{18}$ Ibid., hal. 54.
} 


\section{Pembahasan}

\section{Sekilas World Trade Organization}

World Trade Organization (WTO) atau Organisasi Perdagangan Dunia adalah badan antar-pemerintah, yang mulai berlaku 1 Januari 1995. Tugas utamanya adalah mendorong perdagangan bebas, dengan mengurangi dan menghilangkan hambatan-hambatan perdagangan seperti tarif dan non tarif (misalnya regulasi); menyediakan forum perundingan perdagangan internasional; penyelesaian sengketa dagang dan memantau kebijakan perdagangan di negara-negara anggotanya. ${ }^{19}$

WTO merupakan metamorfosis dari Perjanjian Umum Bea Masuk dan Perdagangan atau GATT (General Agreement on Tariffs and Trade) yang didirikan tahun 1947, sebagai bagian dari kesepakatan di Bretton Woods, Amerika. Sejak 1947 ada tujuh perundingan dagang dimana Putaran Uruguay adalah perundingan paling akhir yang terpanjang (berlangsung dari September 1986 hingga April 1994), rumit dan penuh kontroversi sebelum melahirkan WTO. ${ }^{20}$

Berbeda dengan GATT yang menyusun aturan main di bidang perdagangan internasional, tetapi bukan sebuah institusi; sementara metamorfosisnya yaitu WTO adalah sebuah institusi dengan aturan yang jelas serta daya penegakan yang kuat. Dengan disahkan berdirinya WTO, maka semua kesepakatan perjanjian GATT kemudian diatur di dalam WTO plus isuisu baru yang sebelumnya tidak diatur seperti perjanjian TRIPs (Hak atas Kekayaan Intelektual yang terkait dengan perdagangan), Jasa (GATS mengenai sektor jasa), dan aturan investasi (TRIMs). ${ }^{21}$

WTO mempunyai anggota 149 negara serta 32 negara pengamat yang sudah mendaftar untuk menjadi anggota. Perjanjian WTO mengikat secara hukum. Negara anggota yang tidak mematuhi perjanjian bisa diadukan oleh negara anggota lainnya karena merugikan mitra dagangnya, serta menghadapi sanksi perdagangan yang diberlakukan oleh WTO. Karena itu sistem WTO bisa sangat dominan terhadap anggotanya dan mampu memaksakan aturanaturannya, karena anggota terikat secara legal (legally-binding) dan keputusannya irreversible artinya tidak bisa ditarik kembali.

WTO mengadakan Konferensi tingkat Menteri (KTM) dua tahun sekali. Konferensi Tingkat Menteri pertama diadakan di Singapura tahun 1996, kedua di Geneva tahun 1998 dan sidang ketiga di Seattle, AS tanggal 30 November hingga 3 Desember 1999 dan merupakan sidang terakhir sebelum millenium ketiga. Sidang ketiga ini gagal menyusun Deklarasi Menteri karena dua hal, blockade para demonstran di luar gedung pertemuan sehingga para delegasi

\footnotetext{
${ }^{19}$ Op. Cit., hal. 2.

${ }^{20}$ Ibid., hal. 22-23.

${ }^{21}$ Huala Adolf, Op. Cit., hal. 107-108.
} 
tidak bisa hadir dan perbedaan pandangan yang tajam di ruang sidang antara delegasi dari negara-negara berkembang dan negara-negara maju. ${ }^{22}$

WTO adalah organisasi yang berbasiskan 'aturan-aturan main atau rules' yang merupakan hasil perundingan. Aturan tersebut disebut juga 'perjanjian atau kesepakatan (agreements). Di atas kertas, perjanjian tersebut haruslah dihasilkan dari serangkaian perundingan yang yang dilakukan oleh semua negara anggota, dan mencerminkan kebutuhan anggota (member driven). Realitasnya, perundingan dan penyusunan naskah awal kesepakatan ditentukan oleh faktor lain, yaitu kekuatan politik negara-negara anggota. Di dalam WTO dikenal ada "power bloc (kelompok kekuasaan)" yang disebut quad atau lazim dikenal dengan "Gang Empat" yang terdiri dari Uni Eropa, Jepang, Amerika Serikat dan Kanada. Walaupun pengambilan keputusan berdasarkan konsensus tetapi kekuasaan riil di tangan negara-negara besar tersebut. ${ }^{23}$

\section{Tujuan dan Fungsi $\mathbf{W T O}^{24}$}

WTO memiliki beberapa tujuan penting, yaitu:

a. Mendorong arus perdagangan antar negara, dengan mengurangi dan menghapus berbagai hambatan yang dapat mengganggu kelancaran arus perdagangan barang dan jasa;

b. Memfasilitasi perundingan dengan menyediakan forum negosiasi yang lebih permanen. Hal ini mengingat bahwa perundingan perdagangan internasional dimasa lalu prosesnya sangat kompleks dan memakan waktu. ${ }^{25}$

Tujuan penting lainnya adalah untuk penyelesaian sengketa, mengingat hubungan dagang sering menimbulkan konflik-konflik kepentingan.

Fungsi utama WTO adalah untuk memberikan kerangka kelembagaan bagi hubungan perdagangan antara negara anggota dalam implementasi perjanjian dan berbagai instrumen hukum termasuk yang terdapat di dalam Annex Persetujuan WTO.Secara khusus, berdasarkan Pasal III Persetujuan WTO ditegaskan 5 (lima) fungsi WTO yaitu: ${ }^{26}$

a. Implementasi dari Persetujuan WTO;

b. Forum untuk perundingan perdagangan;

c. Penyelesaian sengketa;

d. Mengawasi kebijakan perdagangan;

e. Kerjasama dengan organisasi lainnya.

\footnotetext{
${ }^{22}$ Hira Jhamtani, Op. Cit., hal. 10-11.

${ }^{23}$ Ibid., hal. 44.

${ }^{24}$ Mochamad Slamet Hidayat, Op. Cit., hal. 1.

${ }^{25}$ Ibid.

${ }^{26}$ H.S. Kartadjoemena, “GATT, WTO dan Hasil Uruguay Round”, hal. 37-38.
} 


\section{Persetujuan-persetujuan WTO}

Persetujuan-persetujuan dalam WTO mencakup barang, jasa, dan kekayaan intelektual yang mengandung prinsip-prinsip utama liberalisasi. Di dalamnya terdapat berbagai komitmen negara-negara untuk membuka pasar dan menurunkan tarif dan hambatan perdagangan lainnya secara individual. Dalam persetujuan WTO juga terdapat ketentuan penyelesaian sengketa antar negara anggota dan perlakuan khusus dan berbeda (special and differential treatment) untuk negara-negara berkembang. Sebagai konsekuensinya, negaranegara anggota diminta membuat kebijakan-kebijakan perdagangan yang transparan yang merujuk pada ketentuan-ketentuan yang dipakai dalam WTO, sebagaimana yang diuraikan dibawah ini:

1) Persetujuan Bidang Pertanian

Pertanian menjadi perhatian utama dalam negosiasi perdagangan karena selama ini disadari sering terjadi distorsi perdagangan atas produk-produk pertanian karena pengenaan kouta impor dan pemberian subsidi domestik maupun subsidi ekspor.

Tujuan persetujuan bidang pertanian adalah untuk melakukan reformasi perdagangan dalam sektor pertanian dan membuat kebijakan-kebijakan yang lebih berorientasi pasar. ${ }^{27}$

2) Persetujuan Mengenai Tekstil

Sejak tahun 1974 sampai berakhirnya Putaran Uruguay, perdagangan tekstil diatur oleh MFA (Multifibre Arrangement), suatu kerangka kerja perjanjian bilateral atau aksi unilateral yang membentuk sistem kuota impor ke negera-negara yang industrinya sedang menghadapi kerugian akibat peningkatan impor yang cepat. Sejak tahun 1995, Persetujuan WTO di bidang Tekstil dan Pakaian Jadi (Agreement on Textiles and Clothing/ATC) menggantikan MFA. ${ }^{28}$

3) Persetujuan Bidang Jasa

The General Agreement on Trade in Service (GATS) adalah peraturan mengikat pertama yang mencakup perdagangan internasional dalam sektor jasa. GATS beroperasi dalam tiga tingkatan:

(a) Teks utama berisikan prinsip-prinsip umum dan berbagai kewajiban;

(b) Lampiran (annexes) yang terdiri dari peraturan untuk sektorsektor khusus;

(c) Komitmen negara-negara anggota untuk membuka akses bagi pasar mereka. ${ }^{29}$

\footnotetext{
${ }^{27}$ Ibid., hal. 25.

${ }^{28}$ Ibid., hal. 29.

${ }^{29}$ Ibid., hal. 30.
} 
4) Hak Atas Kekayaan Inteletual (HAKI)/TRIPs

Putaran Uruguay menghasilkan Persetujuan WTO mengenai Hak Atas Kekayaan Intelektual yang terkait dengan perdagangan (Agreement on Trade Related Aspects of Intellectual Property Rights/TRIPs). Persetujuan tersebut mencakup 5 (lima) hal, yaitu:

(a) Prinsip-prinsip dasar sistem perdagangan dan persetujuan bidang HAKI (principles);

(b) Perlindungan yang cukup terhadap HAKI (protection);

(c) Penegakan hukum bidang HAKI (enforcement);

(d) Penyelesaian sengketa (dispute settlement);

(e) Pengaturan khusus yang diberlakukan selama periode transisi (special transitional arrangement). ${ }^{30}$

5) Anti-Dumping, Subsidi dan Tindakan Pengamanan (Safeguards)

Peraturan-peraturan anti-dumping yang berlaku sekarang adalah hasil revisi dari Putaran Tokyo, dimana tidak semua anggota GATT menjadi pihak dan merupakan hasil Putaran Uruguay. Persetujuan WTO Anti-Dumping memuat beberapa modifikasi sebagai berikut:

(a) Peraturan yang lebih rinci untuk memperhitungkan tingkat dumping;

(b) Prosedur yang terinci untuk memulai (initiation) dan melaksanakan investigasi;

(c) Peraturan untuk implementasi dan jangka waktu pengenaan antidumping (yang biasanya berlaku selama 5 tahun);

(d) Standar tertentu untuk penyelesaian sengketa anti-dumping. ${ }^{31}$

Persetujuan subsidi dan tindakan-tindakan imbalan (Agreement on Subsidies and Countervailing Measures) memuat aturan mengenai subsidi dan tindakan-tindakan yang dapat dilakukan untuk "melawan" tindakan subsidi yang dilakukan negara lain dengan mengenakan bea masuk tambahan.

6) Hambatan Non-Tarif

WTO juga mempunyai persetujuan-persetujuan untuk mengatasi kendala teknis, birokrasi dan peraturan yang menghambat perdagangan seperti:

(a) Peraturan-peraturan teknis dan standarisasi (technical regulations and standards);

(b) Lisensi impor (import lisencing);

(c) Pemeriksaan sebelum pengapalan (pre-shipment inspection);

(d) Aturan mengenai asal produk (rules of origin);

(e) Tindakan-tindakan yang terkait dengan investasi (investment measure $).{ }^{32}$

\footnotetext{
${ }^{30}$ Ibid., hal. 35 .

${ }^{31}$ Ibid., hal. 40 .
} 
7) Persetujuan Plurilateral

Ada 4 (empat) persetujuan yang dinegosiasikan dalam Putaran Tokyo yang hanya ditandatangani oleh sebagian kecil anggota saja dan tidak bersifat mengikat bagi seluruh anggota WTO, yang disebut persetujuan plurilateral. Empat persetujuan tersebut adalah:

(a) Perdagangan pesawat sipil (trade in civil aircraft);

(b) Pengadaan/pembelian pemerintah (government procurement);

(c) Produk susu olahan (dairy product);

(d) Daging olahan (bovine meat). ${ }^{33}$

\section{Agreement on Agriculture Dalam World Trade Organization}

Uruguay Round menjadi putaran yang paling penting dalam sistem perdagangan internasional dibawah GATT. Putaran terakhir sekaligus terpanjang yang berlangsung sejak tahun 1986-1994 ini menjadi penting karena beberapa hal. Pertama, bila dalam perundingan sebelumnya, mulai dari Geneva Round 1947 sampai Geneva Round 1986, cakupan perundingan berkisar pada masalah tariff dan non-tariff. maka pada Uruguay Round telah meluas yaitu mencakup GATT, ${ }^{34}$ GATS (General Agreement on Trade and Services) ${ }^{35}$ dan TRIPs. ${ }^{36}$ Hal kedua adalah pembentukan WTO yang resmi berlaku 1 Januari 1995. WTO hadir sebagai institusi yang mengikat secara hukum (legally binding) dengan aturan main yang jelas, memiliki badan penyelesaian sengketa (dispute settlement body) serta keputusan yang bersifat irreversible (tidak dapat ditarik kembali).

Sejak era Organisasi Perdagangan Dunia (WTO) berjalan, ada 2 (dua) perubahan penting yang perlu diamati, yaitu: pertama, Harga komoditas pangan merosot tajam dalam nilai US\$. Kedua, Terjadinya pergeseran pola produksi komoditas pangan dari negara-negara yang kurang memiliki keunggulan komparatif ke negara-negara yang memiliki keunggulan komparatif tinggi. Dengan demikian, Liberalisasi perdagangan telah membawa kesulitan baru bagi petani kecil di negara berkembang. ${ }^{37}$

${ }^{32}$ Ibid., hal. 42.

${ }^{33}$ Ibid., hal. 45 .

34 GATT mengatur perdagangan dan liberalisasi barang, termasuk di dalamnya pertanian (agriculture), keamanan pangan dan standar kesehatan hewan dan tanaman (sanitary and phytosanitary), tekstil dan pakaian jadi (textile and clothing), standar produk (technical barriers to trade), tindakan investasi yang terkait dengan perdagangan (TRIMs), tindakan anti dumping (anti-dumping), penilaian pabean (custom valuation), pemeriksaan sebelum pengapalan (pre-shipment inspection), ketentuan asal barang (rules of origin), lisensi impor (import licensing), subsidi dan tindakan imbalan (subsidies and countervailing measures), dan tindakan pengamanan (safeguards)

${ }^{35}$ GATS mengatur perdagangan jasa, meliputi pergerakan tenaga kerja (movement of natural persons), transportasi udara (air transportation), jasa keuangan (financial services), perkapalan (shipping), dan telekomunikasi (telecommunication).

\footnotetext{
${ }^{36}$ TRIPs mengatur perdagangan yang terkait dengan haKi (hak kekayaan intelektual).
} 
Lahirnya WTO, 1 januari 1995, menggantikan GATT, secara otomatis membawa sektor pertanian masuk dalam kerangka perdagangan multilateral lewat Agreement on Agriculture (AoA). Tujuan dari AoA ini pada dasarnya adalah untuk memperluas liberalisasi perdagangan di bidang pertanian dan secara bertahap mengurangi distorsi perdagangan sesuai dengan aturan di dalam GATT.38 Aturan yang dimaksud adalah bahwa jenis proteksi yang bersifat kuantitatif tidak diperbolehkan dan proteksi tersebut harus diterapkan secara non-diskriminasi sesuai asas most favored nations.39

Seperti diketahui, ekspor negara berkembang lebih banyak berupa bahan mentah produk pertanian. Hanya ada 2 (dua) perjanjian yang menguntungkan negara sedang berkembang yang berhasil masuk ke dalam WTO, yaitu pertanian dan tekstil. Aspek positif dari Agreement on Ariculture (AoA) adalah dengan masuknya pertanian dalam peraturan perdagangan multilateral, maka negara maju yang selama ini mensubsidi produksi dan ekspor pertanian harus tunduk pada peraturan menghapuskan segala distorsi perdagangan, diantaranya adalah dengan mengurangi subsidi tersebut. 40

Negara maju sebagai penghasil dan eksportir besar hasil pertanian, selama ini memberlakukan proteksi ketat, memberikan subsidi besar kepada para petani mereka, dan menyediakan subsidi ekspor. Hal ini merugikan negara pengekspor hasil pertanian lainnya, terutama negara-negara miskin dan berkembang yang memiliki kemampuan sumber daya terbatas. Kepentingan negara berkembang berbeda dari negara maju. Keunggulan banding Dunia Ketiga umumnya adalah ekspor hasil pertanian dalam bentuk bahan mentah atau bahan baku untuk diolah lebih lanjut. Ekspor komoditas semacam ini sering menjadi satu-satunya sumber devisa bagi negara tertentu, tetapi harganya di pasar internasional sering berfluktuatif tanpa dapat dikendalikan.

Pada dasarnya, Agreement on Agriculture (AoA) mengandung 3 (tiga) unsur utama, yaitu: ${ }^{41}$

a. Pengurangan subsidi ekspor;

b. Pengurangan dukungan (subsidi) dalam negeri;

c. Akses Pasar.

Perundingan yang berhubungan dengan akses pasar, antara lain membahas masalah bentuk formula penurunan tariff, penjabaran konsep Special Product (SP) dan Special Safeguard Mechanism (SSM) dalam framework, masalah Sensitive Products untuk negara maju, masalah tariff

37 Beddu Amang, Harga Pangan Merosot Tajam Dalam Era WTO, "Warta Intra Bulog", No.07/XXV/Pebruari/2000, hal. 5.

38 Lidya Christin Sinaga, Isu pertanian dan Respon Masyarakat Sipil di Indonesia, <http://jurnal.dikti.go.id/jurnal/detil/id/24:60016/q/pengarang:CHRISTIN\%20/offset/0/limit/15>, diakses tanggal 20 April 2011.

\footnotetext{
${ }^{39}$ Khudori, Neoliberalisme Menumpas Petani (Yogyakarta: Resist Book, 2004). hal. 60.

${ }^{40}$ Mochamad Slamet Hidayat, Op. Cit., hal. 53.

${ }^{41}$ Hira Jhamtani, Op. Cit., hal. 53.
} 
capping, tariff quota, preferences, tropical products, dan newly accededmembers. Perundingan yang berhubungan dengan Subsidi Ekspor, antara lain meliputi penentuan kriteria untuk parallelism (penghapusan ekspor subsidi yang dilakukan secara paralel dengan penghapusan komponen subsidi pada kredit ekspor), aspek subsidi dari State Trading Enterprises (STE), food aid dan differential export taxes yang dapat diterima oleh negara-negara Eropa agar mereka bersedia menghapus seluruh subsidi ekspor, menentukan aspek subsidi dari STE, food aid, kredit ekspor dan masalah monitoring. Adapun perundingan mengenai Subsidi Domestik antara lain membahas masalah penentuan formula yang dapat memotong subsidi domestic secara progresif semakin tinggi tingkat subsidi semakin besar pemotongannya, penerapan konsep product specific untuk subsidi dalam kategori Amber Box dan Blue Box, masalah pemotongan de minimis yang terkait dengan subsidi Blue Box, masalah disiplin, monitoring dan pengetatan aturan Blue Box, serta titik awal pemotongan Blue Box mengingat subsidi dalam kategori ini tidak di-bound. ${ }^{42}$

\section{Penutup}

\section{Simpulan}

Berdasarkan uraian diatas, maka dapat ditarik kesimpulan bahwa lahirnya World Trade Organization, 1 Januari 1995, menggantikan GATT, secara otomatis membawa sektor pertanian masuk dalam kerangka perdagangan multilateral lewat Agreement on Agriculture (AoA). Tujuan dari AoA ini pada dasarnya adalah untuk memperluas liberalisasi perdagangan di bidang pertanian dan secara bertahap mengurangi distorsi perdagangan sesuai dengan aturan di dalam GATT. Pada dasarnya, Agreement on Agriculture (AoA) mengandung 3 (tiga) unsur utama, yaitu pengurangan subsidi ekspor, pengurangan dukungan (subsidi) dalam negeri, dan akses Pasar. Implikasi Agreement on Agriculture dalam WTO dapat dilihat dari segi Akses Pasar, Dukungan Domestik dan Subsidi Ekspor.

\section{Saran}

Berdasarkan penelitian dalam tulisan ini, penulis mengajukan rekomendasi kepada Pemerintah Republik Indonesia terkait dengan tema penelitian. rekomendasi tersebut adalah revitalisasi peran negara dalam pengelolaan pasar pertanian domestik dengan cara mengintegrasikan pembangunan pertanian dalam negeri dan politik luar negeri, khususnya dalam perundingan-perundingan perdagangan yang terkait dengan kebijakan pertanian di dalam negeri.

${ }^{42}$ Ibid., hal. 54. 


\section{Daftar Pustaka}

\section{Buku Teks/Makalah}

Adolf, Huala. Hukum Perdagangan Internasional. Raja Grafindo Persada. Jakarta. 2005.

Penyelesaian Sengketa Dagang Dalam World Trade Organization (WTO). Mandar Maju. Bandung. 2005.

Hata. Perdagangan Internasional Dalam Sistem GATT dan WTO (Aspek-aspek Hukum dan Non Hukum). Refika Aditama. Bandung. 2006.

Hidayat, Mochamad Slamet. et.al. Sekilas WTO (World Trade Organization) Edisi Keempat. Direktorat Perdagangan, Perindustrian, Investasi dan HKI Direktorat Jenderal Multilateral Departemen Luar Negeri. Jakarta. tanpa tahun.

Jhamtani, Hira. WTO dan Penjajahan Kembali Dunia Ketiga. InsistPress. Yogyakarta. 2005.

Kartadjoemena, H.S. GATT, WTO dan Hasil Uruguay Round. Universitas Indonesia-Press. Jakarta. 1997

Khudori, Neoliberalisme Menumpas Petani Resist Book, Yogyakarta. 2004. . Ironi Negeri Beras Insist Press, Yogyakarta. 2008.

Sawit, M. Husein. Liberalisasi Pangan Ambisi dan Reaksi dalam Putaran Doha WTO. Jakarta. Lembaga Penerbit: Fakultas Ekonomi Universitas Indonesia. 2007.

Kiki. P dan Agus D.I., "Notifikasi Produk Pertanian di WTO dan de Minimis untuk Beras".:Bulog, Jakarta. 2003.

Setiawan, Bonnie.Globalisasi Pertanian. The Institute for Global Justice. Jakarta 2003.

et. al. WTO, Kapitalisme, dan Pembangunan Gerakan. The Institute for Global Justice. Media Pembebasan. Jakarta. 2006.

\section{Undang-Undang}

Republik Indonesia Undang-Undang Tentang Agreement Establishing The World Trade Organization (Persetujuan Pembentukan Oorganisasi Perdagangan Dunia). Nomor 7 Tahun 1994. Lembaran Negara Republik Indonesia Tahun 1994 Nomor 57 Tambahan Lembaran Negara Nomor 3564.

Undang-Undang Tentang Pangan Nomor 7 Tahun 1996.Lembaran Negara Republik Indonesia Tahun 1996 Nomor 99. Tambahan Lembaran Negara Republik Indonesia Nomor 3656 
Peraturan Pemerintah Tentang Ketahanan Pangan. PP Nomor 68 Tahun 2002. Lembaran Negara Republik Indonesia Tahun 2002 Nomor 142. Tambahan Lembaran Negara Republik Indonesia Nomor 4254.

\section{Artikel/Jurnal}

Amang, Beddu. Harga Pangan Merosot Tajam Dalam Era WTO, Warta intra Bulog No.07/XXV/Pebruari/2000.

Perdagangan Global: Implikasinya Pada Sektor Pertanian, Warta Intra Bulog No.10/Tahun XXI/Mei/1996.

Sawit, M.Husein. Mengapa “Petani Korea Marah Terhadap WTO”, Warta Intra Bulog Nomor 02/tahunXXXII/Pebruari/2006.

\section{Internet}

<http://www.kemlu.go.id>

$<$ http://www.globaljust.org>

$<$ http://www.wto.org/aoa/legaltext> 